\title{
Mass accumulation rate of detrital materials in Lake Suigetsu as a potential proxy for heavy precipitation: a comparison of the observational precipitation and sedimentary record
}

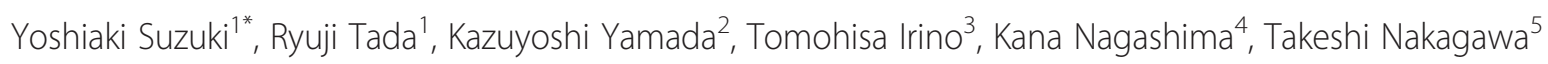
and Takayuki Omori ${ }^{6}$

\begin{abstract}
In the densely populated region of East Asia, it is important to know the mechanism, scale, and frequency of heavy precipitation brought about during the monsoons and typhoons. However, observational data, which cover only several decades, are insufficient to examine the long-term trend of extreme precipitation and its background mechanism. In humid areas, the transport flux of a suspended detrital material through a river system is known to have an empirical power relationship with precipitation. Thus, the sedimentation flux of a fine detrital material could potentially be used as a proxy for reconstructing past heavy precipitation events. To test the idea that the sedimentation flux of detrital materials records past heavy precipitation events (e.g., typhoons), we focused on the detrital flux estimated from the annually laminated sediment of Lake Suigetsu, central Japan, which is capable of accurately correlating the age of detrital flux with the precipitation record. We first established a precise age model (error within \pm 1 year in average) beginning in 1920 A.D. on the basis of varve counting fine-tuned by correlation between event layers with historical floods. The flux of the detrital material $\left(\mathrm{g} / \mathrm{cm}^{2} /\right.$ year) was estimated on the basis of $\mathrm{Al}_{2} \mathrm{O}_{3}$ content $(\mathrm{wt} \%)$, dry bulk density $\left(\mathrm{g} / \mathrm{cm}^{3}\right)$, and sedimentation rate $(\mathrm{cm} /$ year) calculated from the age model. The detrital flux of background sedimentation showed a weak positive correlation with annual and monthly (June and September) precipitation excluding heavy precipitation that exceeded $100 \mathrm{~mm} /$ day. Furthermore, the thickness of instantaneous event layers, which corresponds to several maxima of detrital flux and is correlated with floods that occurred mainly during typhoons, showed a positive relationship with the total amount of precipitation that caused a flood event. This result suggests that the detrital flux maxima (deposition of event layers) record past extreme precipitation events that were likely associated with typhoons that hit the middle part of Honshu Island. Based on this result, the record of typhoon-caused flood events can go back to older period (e.g., last glacial period) on the basis of the occurrence, and thickness, or mass flux of event layers using long sediment cores from Lake Suigetsu.
\end{abstract}

\footnotetext{
*Correspondence: yoshiaki_suzuki@eps.s.u-tokyo.ac.jp

'Department of Earth and Planetary Sciences, Graduate School of Science,

University of Tokyo, 7-3-1 Hongo Bunkyo-ku, Tokyo, Japan

Full list of author information is available at the end of the article
} 


\section{Background}

Since intensities and routes of typhoons affect human activities in Asia, it is important to examine the long-term behavior of typhoons over East Asia. However, it is difficult to quantitatively reconstruct precipitation records with high temporal resolution for periods greater than 100 years because the observational record is limited primarily to the last few decades [Schillereff et al. 2014]. Therefore, it is necessary to develop geological proxies to reconstruct paleotyphoons. Pollen analysis combined with the modern analog method has been used to reconstruct monthly temperature and precipitation [Wright 1967; Nakagawa et al. 2002; Nakagawa et al. 2005; Tarasov et al. 2011]. This method is based on the empirical relationship between vegetation and local climate. However, precipitation estimates obtained from pollen data are averaged over a month or season due to the long timescale of biological response. Thus, this method is not good at recording the recurrence of high-intensity precipitation events such as natural hazards, which have critical effects on human activity. One complementary way to estimate past precipitation is utilizing the flux of detrital materials transported by a river to estimate the water discharge of the river system, while the grain size distributions of the detrital materials record the intensity of the river systems. Particularly, the flux of the detrital material from the river $\left(R F_{\text {det }}\right)$, i.e., the product of river water discharge and the concentration of the suspended detrital material in the river water, is well observed in the present rivers and known to be empirically related to water discharge $(Q)$, as described in Eq. (1),

$$
\mathrm{RF}_{\mathrm{det}}=a \times Q^{b}
$$

The relationship represented by Eq. (1) is known as a rating curve [Arnell 1992; Kazama et al. 2005; Yang et al. 2007; Sadeghi et al. 2008; Kaji and Nihei 2014], where $a$ and $b$ are constants specific to an individual river basin. Since the water discharge of a river system is proportional to the precipitation in its river [Arnell 1992; Milliman and Syvitski 1992; Yang et al. 2007], we can estimate precipitation from the flux of the detrital material recorded in sediments. Because the river water discharge exponentially affects the detrital flux, this method should be especially sensitive to the heavy precipitation events. Therefore, this method is useful for sediments that have high-resolution and precise age-depth models and are found in regions that suffer from heavy precipitation events such as monsoons and typhoons. Thus, this method can be applied to lake sediments in Asia, which have high sedimentation rate and precise age models, and are subjected to heavy precipitation events.

Lake Suigetsu $\left(35^{\circ} 35^{\prime} \mathrm{N}, 135^{\circ} 53^{\prime} \mathrm{E}\right)$ in central Japan is known to have annually laminated (varved) sediment from 70 to $11.6 \mathrm{ka}$, and also from $\sim 350$ years ago to the present
[Fukusawa et al. 1994; Marshall et al. 2012; Nakagawa et al. 2012; Schlolaut et al. 2012]. Also, high-resolution ${ }^{14} \mathrm{C}$ dating has been conducted during the past 52.8 kyrs (average resolution of $\sim 100$ years) [Staff et al. 2011; Bronk Ramsey et al. 2012], allowing the high-resolution estimation of detrital flux throughout the past 70 kyrs. Herein, we examined whether and how heavy precipitation events due to typhoons were recorded in the detrital materials of Lake Suigetsu sediments by comparing the flux of the detrital material reconstructed from the Lake Suigetsu sedimentary record and the observational precipitation record spanning the last 80 years.

\section{Hydrological, geographical, and climatological settings}

Lake Suigetsu is one of the Mikata Five Lakes located in the southern part of the Fukui prefecture in central Japan (Fig. 1a, b). From the upper to the lower stream, Lakes Mikata, Suigetsu, Suga, and Kugushi are connected by narrow channels, and Lake Kugushi is open to the Sea of Japan. The catchment area of Lake Suigetsu is small $\left(8.3 \mathrm{~km}^{2}\right)$ considering the size of the lake itself $\left(4.2 \mathrm{~km}^{2}\right)$. Therefore, the lake water of Lake Suigetsu comes mainly from the catchment of Lake Mikata, which is connected with Lake Suigetsu by a shallow channel. Furthermore, most of the fine detrital materials are considered to have been supplied from the Hasu River. Because coarse detrital grains from the Hasu River are trapped in Lake Mikata, only fine suspended detrital particles can reach Lake Suigetsu [Nakagawa et al. 2012; Schlolaut et al. 2014]. This is a great advantage of using Lake Suigetsu sediments in the present study because detrital materials from the Hasu River can be identified from the grain size distribution (Nagashima $\mathrm{K}$ et al: Asian dust transport during the last one century recorded in Lake Suigetsu sediments, submitted). In 1664, after the Kanbun Earthquake in 1662, an artificial channel called the Urami channel was cut between Lakes Suigetsu and Kugushi, the latter of which is connected to the Sea of Japan. This channel allows the brackish water of Lake Kugushi to flow into Lake Suigetsu, which produces a generally anoxic environment at the bottom of Lake Suigetsu [Fukusawa et al. 1994; Ramsey et al. 2013; Saito-Kato et al. 2013]. Thus, the Lake Suigetsu sediment accumulated since 1664 has clear varves. Although Lake Suigetsu is formed by subsidence in the western side of Mikata Fault (Fig. 1c), no fault movement was observed (historically recorded) after the 1662 Kanbun Earthquake. Therefore, the hydrology and sedimentation of Lake Suigetsu were not changed by fault movement after 1662 .

\section{Methods}

Samples

A short gravity core named SG12-LM3 with a length of approximately $25 \mathrm{~cm}$ was recovered from the 


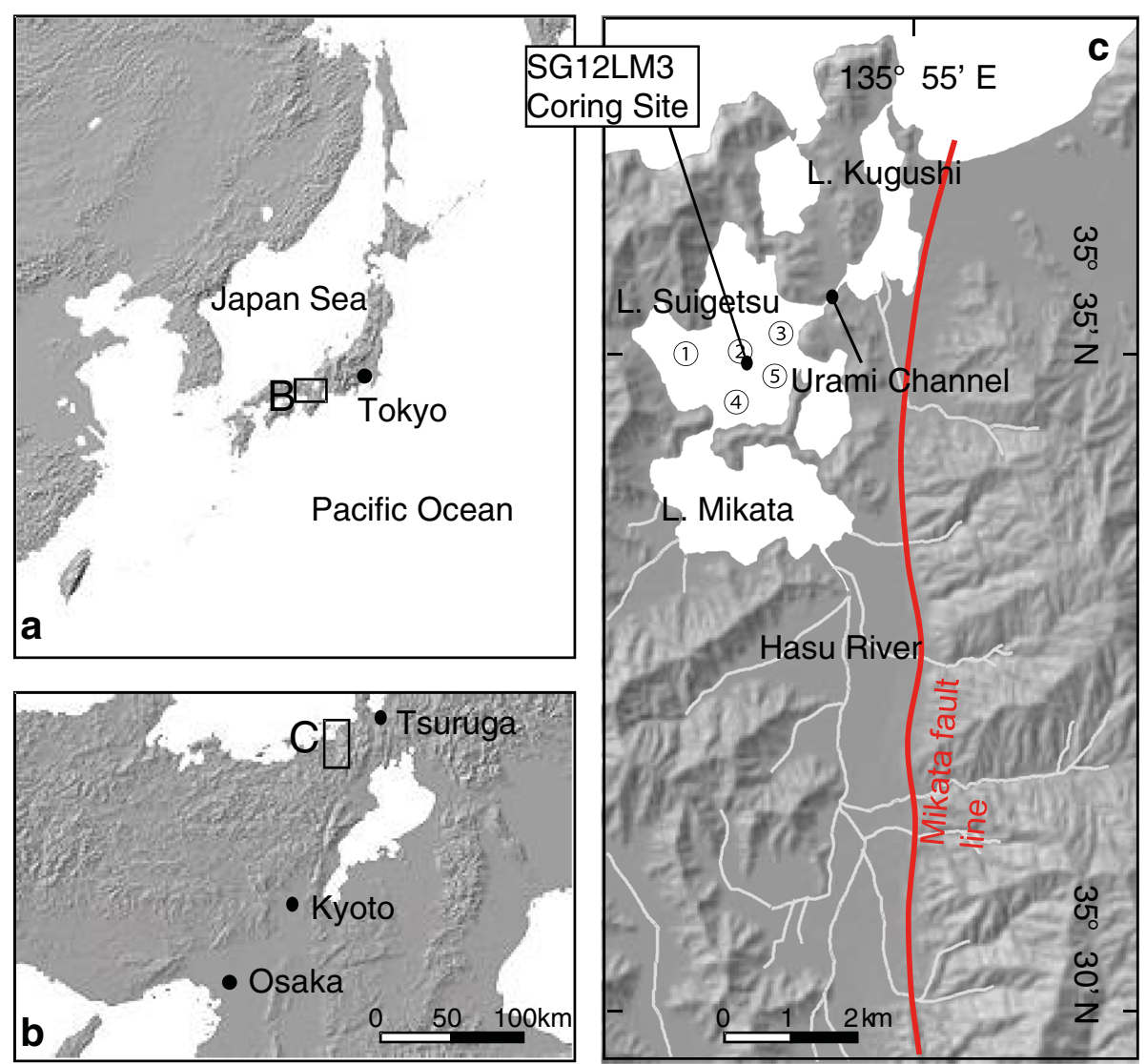

Fig. 1 a-c Location of Lake Suigetsu (modified after Nakagawa et al. 2005). Also shown are the location of core SG12LM3 and other coring sites (shown as numbers)

central part of Lake Suigetsu using a Limnos core sampler [Kansanen et al. 1991] on July 6, 2012. Because a Limnos sampler does not have any mechanical actuator, it can retrieve the sediment-water interface without any disturbance. To correlate and reveal the mechanism of the sedimentation of event layers, additional Limnos core sample was conducted at multiple sites on June 20 and 21, 2014. The sampling points are shown in Fig. 1c, and half-split scanned images are shown in Fig. 9. To determine the chemical composition of the suspended particle material from the Hasu River, 100 liters of river water was collected at the mouth of the Hasu River on October 1, 2012, immediately after the strong precipitation event that occurred during the 17th typhoon in 2012, which went through the central part of Honshu Island. The water was filtered using a Millipore filter (pore diameter $=0.45 \mu \mathrm{m}$ ), and the filtered suspended particle material of the Hasu River was retrieved from the filtrating paper using deionized water.

SG12-LM3 was sent to the University of Tokyo within 40 days after sampling and stored vertically in a refrigerator at $5{ }^{\circ} \mathrm{C}$ for half a year to let the top part of the sediments compact to avoid fluidization during core splitting. The core was then pushed into a tube of the same diameter that was assembled using two tubes cut in half. Next, two thin plastic boards attached together were inserted into the slit between the two half-cut tubes. Slab samples $(20 \times 5 \times 0.7 \mathrm{~cm})$ were taken from a half-split core and subjected to soft X-ray analysis using a SOFTEX CMB-2 in the filming condition of $40 \mathrm{kV} / 2 \mathrm{~mA} / 5 \mathrm{~min}$ exposure time. The remaining part of the core was sliced into subsamples with thicknesses of $6 \mathrm{~mm}$, corresponding to a resolution of $2-3$ years. The sliced samples were weighed in wet condition $\left(W_{\mathrm{w}}, \mathrm{g}\right)$ and then freeze-dried for more than $30 \mathrm{~h}$. The dried samples were weighed $\left(W_{\mathrm{d}}\right)$ again. Grain density $\left(\mathrm{GD}, \mathrm{g} / \mathrm{cm}^{3}\right)$ was measured for dried samples using a He pycnometer (AccuPyc 1330, Micrometrics Instrument Co.) at the Atmospheric and Ocean Research Institute at the University of Tokyo.

\section{Measurement of major elements}

From each dried sample (including suspended particle material sampled from the Hasu River), $\sim 0.6 \mathrm{~g}$ was split and used to make a glass bead. Before making the glass bead, each sample was ignited, and the loss on ignition 
was calculated. X-ray fluorescence (XRF) analysis was conducted to determine the concentrations of 10 major elements $\left(\mathrm{Al}_{2} \mathrm{O}_{3}, \mathrm{SiO}_{2}, \mathrm{TiO}_{2}, \mathrm{Fe}_{2} \mathrm{O}_{3}, \mathrm{MnO}, \mathrm{P}_{2} \mathrm{O}_{5}, \mathrm{Na}_{2} \mathrm{O}\right.$, $\mathrm{CaO}, \mathrm{MgO}$, and $\mathrm{K}_{2} \mathrm{O}$ ) using an XRF spectrometer (PANalytical Axios) equipped with an Rh tube. The $1 \sigma$ values of the measurements were $\pm 0.046 \%$ for $\mathrm{SiO}_{2}$, $0.0035 \%$ for $\mathrm{TiO}_{2}, 0.019 \%$ for $\mathrm{Al}_{2} \mathrm{O}_{3}, 0.0067 \%$ for $\mathrm{Fe}_{2} \mathrm{O}_{3}, 0.0018$ \% for $\mathrm{MnO}, 0.0058$ \% for $\mathrm{MgO}, 0.003 \%$ for $\mathrm{CaO}, 0.0072 \%$ for $\mathrm{Na}_{2} \mathrm{O}, 0.0057 \%$ for $\mathrm{K}_{2} \mathrm{O}$, and $0.0035 \%$ for $\mathrm{P}_{2} \mathrm{O}_{5}$.

\section{Measurements of radioactive nuclides}

Using several sliced and dried samples, the radioactivities of ${ }^{137} \mathrm{Cs}$, ${ }^{210} \mathrm{~Pb}$, and ${ }^{214} \mathrm{~Pb}$ were measured for $14 \mathrm{se}-$ lected samples using an ORTEC GWL-120230-S HPGe (High-Purity Germanium) coaxial well photon detector system with an inner diameter of $17 \mathrm{~mm}$ and an active well depth of $40 \mathrm{~mm}$ at Hokkaido University. ${ }^{137} \mathrm{Cs}$ is a fallout product of nuclear testing, which enables us to constrain the age of the ${ }^{137} \mathrm{Cs}$ peak to the peak age of nuclear testing 1963 A.D. on the basis of the record of nuclear testing [Delaune et al. 1978].

Excess ${ }^{210} \mathrm{~Pb}$, defined as the difference between the radioactivities of measured ${ }^{210} \mathrm{~Pb}$ and ${ }^{214} \mathrm{~Pb}$, is a type of radioactive nuclide provided from the ground surface through the atmosphere that decays with a half-life time of 22.3 years. This nuclide can be used to estimate the mean mass accumulation rate (MAR, $\mathrm{g} / \mathrm{cm}^{3} /$ year) of the sediment assuming that sedimentation flux is constant. Here, ${ }^{210} \mathrm{~Pb}$ is assumed to come from the sediment itself and the ground surface. ${ }^{214} \mathrm{~Pb}$ is equal to the activity of sediment-originated ${ }^{210} \mathrm{~Pb}$, assuming a constant mass accumulation rate $\left(\mathrm{g} / \mathrm{cm}^{2} /\right.$ year $)$ and the radiation equilibrium of the uranium series have been established [Kato et al. 2003]. One to two grams of a dried sample was weighed within an error of $\pm 0.5 \mathrm{mg}$ and placed into a plastic tube. The tube was then placed in the wellshaped Ge detector. The measurement time was $48 \mathrm{~h}$. The gamma-ray spectra were obtained using a Seiko EG\&G MCA7600 multichannel analyzer. The analytical errors (detection limits) of ${ }^{137} \mathrm{Cs},{ }^{210} \mathrm{~Pb}$, and ${ }^{214} \mathrm{~Pb}$ were $0.006(0.018) \mathrm{Bq} / \mathrm{g}, 0.28(0.83) \mathrm{Bq} / \mathrm{g}$, and 0.010 (0.030) $\mathrm{Bq} / \mathrm{g}$, respectively.

\section{Lithology and petrographical observation}

Based on the macroscopic observation of a half-split core and the microscopic observation of smear slides, the Lake Suigetsu sediment is dominantly composed of diatom frustules, clay- to silt-sized detrital materials, organic materials, and black-colored minerals showing grain aggregation considered to be siderite or pyrite formed in the water column. Clear $\sim \mathrm{mm}$-scale lamination composed of alternating black-gray (mainly diatom shells and organic material), brown (mainly diatom frustules and aggregated siderite), and gray (mainly detrital material) layers are observed throughout the core.

Light-gray fine-grained detrital layers with thicknesses of a few millimeters with normal grading and a sharp basal contact with the underlying sediment are also observed at intervals of every centimeter interval (Table 1). These characteristics of event layers identified in SG12-LM3 are similar to those of the event layers of flood origin reported by a previous study based on comparison with the chemical compositions of basement rocks in the surrounding area [Schlolaut et al. 2014]. We call these gray and graded layers with sharp basal contact as "event layers" because these characteristics indicate that these layers were deposited in a short time by settling from thick, suspended, particulate matter. When assuming precipitation of $100 \mathrm{~mm} /$ day and settling grains with diameter of $3 \mu \mathrm{m}$ [Nagashima et al., submitted] following Stokes' law, suspended detrital material from Lake Mikata stays in Lake Suigetsu for about 3 weeks.

\section{Varve counting}

Next we show 4 steps showing procedure of constructing an age model. Varve counting was conducted based on soft X-ray images to construct an age model for the SG12-LM3 core. Each varve is defined as a set of a continuous lower light (high-density) layer and upper dark (low-density) layer observed in the soft X-ray image. The basal boundary of each varve was determined as the steepest point of the change in brightness change from the underlying dark (low-density) layer to the overlying light (high-density) layer; the former represents the organic amorphous material accumulated during summer, and the latter represents the siderite and/or clay layer accumulated during winter [Schlolaut et al. 2012]. Following the previous varve counting of Lake Suigetsu sediments (Schlolaut et al. 2012), when the varve does not have clear density contrast or is not horizontally continuous (hereafter called unclear varve), we consider that it formed at a rate of 1 layer per $0.5 \pm$ 0.5 years (Additional file 1: Figure S1).

The laminae, which have sharp basal contact with the underlying layer and gradual contact with the overlying layer in the soft X-ray images and are characterized by higher density (light gray to white in the images) than adjacent laminae, were defined as event layers (Additional file 1: Figure S1). Event layers were excluded from the annual layer counting because they were considered to have accumulated in a short time on the basis of the bottom's sharp contact. Because there was no clear lamination from depths of 17.3 to $19.1 \mathrm{~cm}$, we considered this part as temporarily bioturbated and interpolated the sedimentation rate 
Table 1 List of age control points based on the correlation between the event layers and historically recorded floods

\begin{tabular}{|c|c|c|c|c|c|c|c|}
\hline \multicolumn{4}{|c|}{ List of event layer } & \multicolumn{4}{|c|}{ List of historically recorded flood } \\
\hline $\begin{array}{l}\text { Event layer } \\
\text { Number }\end{array}$ & $\begin{array}{l}\text { bottom depth of event } \\
\text { layer (distance from core } \\
\text { top, } \mathrm{cm} \text { ) }\end{array}$ & $\begin{array}{c}\text { Varve count age (additional } \\
\text { constraint from 137Cs) } \\
\text { (A.D.) }\end{array}$ & $\begin{array}{c}\text { Event layer } \\
\text { thickness }(\mathrm{mm})\end{array}$ & $\begin{array}{l}\text { Flood } \\
\text { Number }\end{array}$ & $\begin{array}{c}\text { Date } \\
\text { (yr/month/day) }\end{array}$ & $\begin{array}{l}\text { Total precioitation in } \\
\text { Tsuruga }(\mathrm{mm})\end{array}$ & $\begin{array}{l}\text { The cause of flood } \\
\text { T: Typhoon } \\
\text { TD: Tropical } \\
\text { depression } \\
\text { B: Baiu (rainy } \\
\text { season) }\end{array}$ \\
\hline E1 & 0.6 & $2009-2011$ & 1.1 & - & - & - & - \\
\hline E2 & 2.45 & 2004-2007 & 0.65 & F1 & $10 / 21 / 2004$ & 150 & $\mathbf{T}$ \\
\hline E3*1 & 3.9 & 1996.5-2001.5 & 0.95 & F2 & 8/14/1999 & 149 & TD \\
\hline E4*1 & 4.2 & $1996.5-2001.5$ & 0.65 & F3 & $9 / 22 / 1998$ & 130 & $\mathbf{T}$ \\
\hline E5 & 6.3 & 1987.5-1993.5 & 1.05 & F4 & 9/20/1990 & 260 & $\mathbf{T}$ \\
\hline- & - & & - & F5 & $8 / 1 / 1982$ & 214 & $\mathrm{~T}$ \\
\hline E6*2 & 10.38 & 1972.5-1979.5 & 0.55 & F6 & 9/9/1976 & 124 & $\mathbf{T}$ \\
\hline E7 & 10.6 & $1969.5-1979.5$ & 0.3 & - & - & - & - \\
\hline$E 8 * 3$ & 10.88 & $1969.5-1979.5$ & 0.9 & F7 & $8 / 23 / 1975$ & 194 & $\mathbf{T}$ \\
\hline E9*4 & 11.3 & 1967.5-1979.5 & 0.6 & F8 & $9 / 17 / 1972$ & 216 & $\mathbf{T}$ \\
\hline E10*4 & 11.4 & 1967.5-1979.5 & 1.15 & F9 & 7/13/1972 & 477 & B \\
\hline E11 & 12.52 & $1963.5-1975.5$ & 1.1 & - & - & - & - \\
\hline E12 & 12.9 & $1962.5-1974.5$ & 1.5 & - & - & - & - \\
\hline E13*4,5 & 13.24 & $1962.5-1974.5$ & 1.8 & F10 & $9 / 17 / 1965$ & 410 & $\mathbf{T}$ \\
\hline E14*4,5 & 13.4 & 1962.5-1974.5 & 2.85 & F11 & 9/10/1965 & 95 & $\mathbf{T}$ \\
\hline E15 & 14.4 & $1958.5-1971.5$ & 1.5 & - & - & - & - \\
\hline E16*6 & 15.05 & $1954.5-1968.5$ & 0.65 & F12 & $8 / 14 / 1959$ & 258 & $\mathbf{T}$ \\
\hline E17 & 16.15 & $\begin{array}{c}1947.5-1963.5 \\
\text { (older than } 1954 \text { ) }\end{array}$ & 3.55 & F13 & $9 / 25 / 1953$ & 311 & $\mathbf{T}$ \\
\hline
\end{tabular}

Gray shades indicate the pairs used as age-control points. These pairs are consistent with the estimated varve count age for each event layer, except those symbolized as asterisks, which require further constraining

$T$ typhoon, $T D$ tropical depression, $B$ Baiu (rainy season)

*1: Two neighboring event layers in the range of 5 years are compared to two floods which occurred in 1998 and 1999

*2: Based on varve re-counting from E5, age of E6 ranges from 1976 to 1977

*3: Based on varve re-counting from E6, ages of E8 ranges from 1973 to 1976

*4: Two neighboring event layers without varve between the layers are compared to two floods which occurred in 1 year (1972 and 1965)

*5: Based on varve re-counting from E16, age of E14 ranges from 1965 to 1967

*6: Based on varve re-counting from E17, age of E16 ranges from 1958 to 1960

(cm/year) based on the average varve thickness in other parts $(2.5 \pm 1.2 \mathrm{~mm} /$ year $)$.

On the basis of the lamina counting assuming that the top of the core formed in 2012, we estimated the age of each lamina and cumulated preliminary dating error of each lamina in the SG12-LM3 core. The results are plotted versus depth in Fig. $2 E$.

\section{Verification of varve count age using the ${ }^{210} \mathrm{~Pb}$ and ${ }^{137} \mathrm{Cs}$ results}

As a second step, we used ${ }^{210} \mathrm{~Pb}$ and ${ }^{137} \mathrm{Cs}$ to verify age model based on varve counting. Figure $2 D$ shows the depth profiles of excess ${ }^{210} \mathrm{~Pb}$ and ${ }^{137} \mathrm{Cs}$ concentrations. The profile of $15{ }^{210} \mathrm{~Pb}$ data against mass accumulation $\left(\mathrm{g} / \mathrm{cm}^{2}\right)$ was fit by a decaying curve, as shown in Fig. $2 F$. The age model based on ${ }^{210} \mathrm{~Pb}$ (Fig. 2e) shows an age of 1925 A.D.
$( \pm 3)$ at the bottom of the core. At the same point, varve counting suggested an age of 1930 A.D. ( \pm 10 varve count years). Therefore, the ${ }^{210} \mathrm{~Pb}$-based age-depth model agrees with the varve count age model within the error.

The first appearance of ${ }^{137} \mathrm{Cs}$ is known to correspond to the beginning of nuclear testing in 1954 A.D., and the peak ${ }^{137} \mathrm{Cs}$ concentration corresponds to 1963 A.D., when nuclear testing was at its peak [Delaune et al. 1978]. In Fig. 2d, ${ }^{137}$ Cs appears (1954 A. D.) at a depth of $15.4-15.8 \mathrm{~cm}$, while the depth of the varve count age of 1954 A.D. is at a depth of $15.2-20.4 \mathrm{~cm} .{ }^{137} \mathrm{Cs}$ has a clear peak (1963 A. D.) at a depth of $14.0-15.2 \mathrm{~cm}$, while the depth of the varve count age of 1963 A.D. is 13.4$15.8 \mathrm{~cm}$. These results show that the varve count age model is consistent with the ${ }^{137} \mathrm{Cs}$-based ages within the error $( \pm 10$ years). 


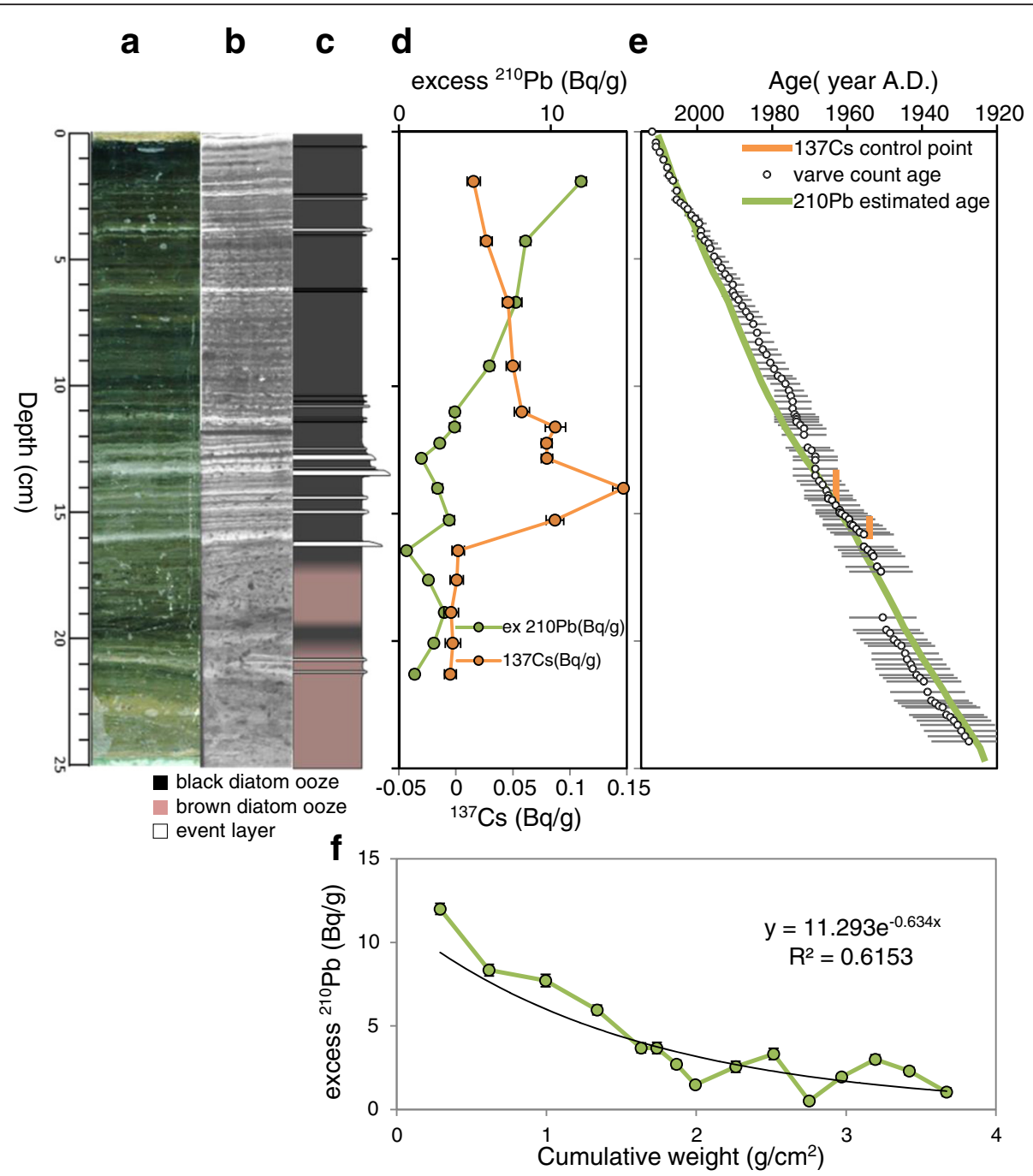

Fig. 2 (A) Scanned image (color intensified). (B) Soft X-ray image (color intensified and length adjusted with A). (C) Columnar section. (D) ${ }^{210} \mathrm{~Pb}(\mathrm{~Bq} / \mathrm{g})$ and ${ }^{137} \mathrm{Cs}\left(\mathrm{Bg} / \mathrm{g}\right.$ ) excess profiles. (E) Varve count age of the SG12LM3 core. $(F)$ The ${ }^{210} \mathrm{~Pb}$ decay curve against the cumulative weight $\left(\mathrm{g} / \mathrm{cm}^{2}\right)$. The ${ }^{137} \mathrm{CS}$ control points (orange points) and estimated ages based on ${ }^{210} \mathrm{~Pb}$ (green line) are also shown in $(E)$

\section{Fine-tuning based on the correlation between event} layers and flood events

The result of step 2 revealed that the varve count age model is accurate for the past 90 years within an error of $\pm 5-10$ years. To further constrain the age model, we compared the ages of event layers with historical flood events. All of event layers found in the SG12-LM3 core were interpreted to have been formed by short-term events such as flood failures, as inferred from their sharp contact with the underlying part, normal grading, and light-gray color. Smear slide observation revealed that the even layers are mainly composed of detrital materials without diatom frustules, siderite, or pyrite. On the other hand, flood events that affected human activities were compiled by the staff of a local museum (Jomon Museum) (Mikata Town History 1990; Memoric magazine of 50th anniversary of Kaminaka-Town organization and Center of Kaminaka-Town residents 2004; Looking back the history of Mikata-Town and Mikata-Town 2005). There are 17 event layers and 13 historically recorded flood events throughout SG12LM3 core (Table 1). Within the error of the varve age model, event layer E3 is correlated with historically recorded flood event F2. After this pair was correlated, E3 and E4 were correlated with two floods F2 and F3 that occurred in 1998. Subsequently, E5 was correlated with F4, and the age range was reduced. The same steps were applied from the upper or lower control point. Consequently, 12 event layers could be compared to historically recorded flood events (Fig. 3 and Table 1). Then, using the 14 age-control points (Table 1), 2 from the ${ }^{137} \mathrm{Cs}$ profile and 12 from identified flood events, we finely tuned the varve age model to explain the age difference between 


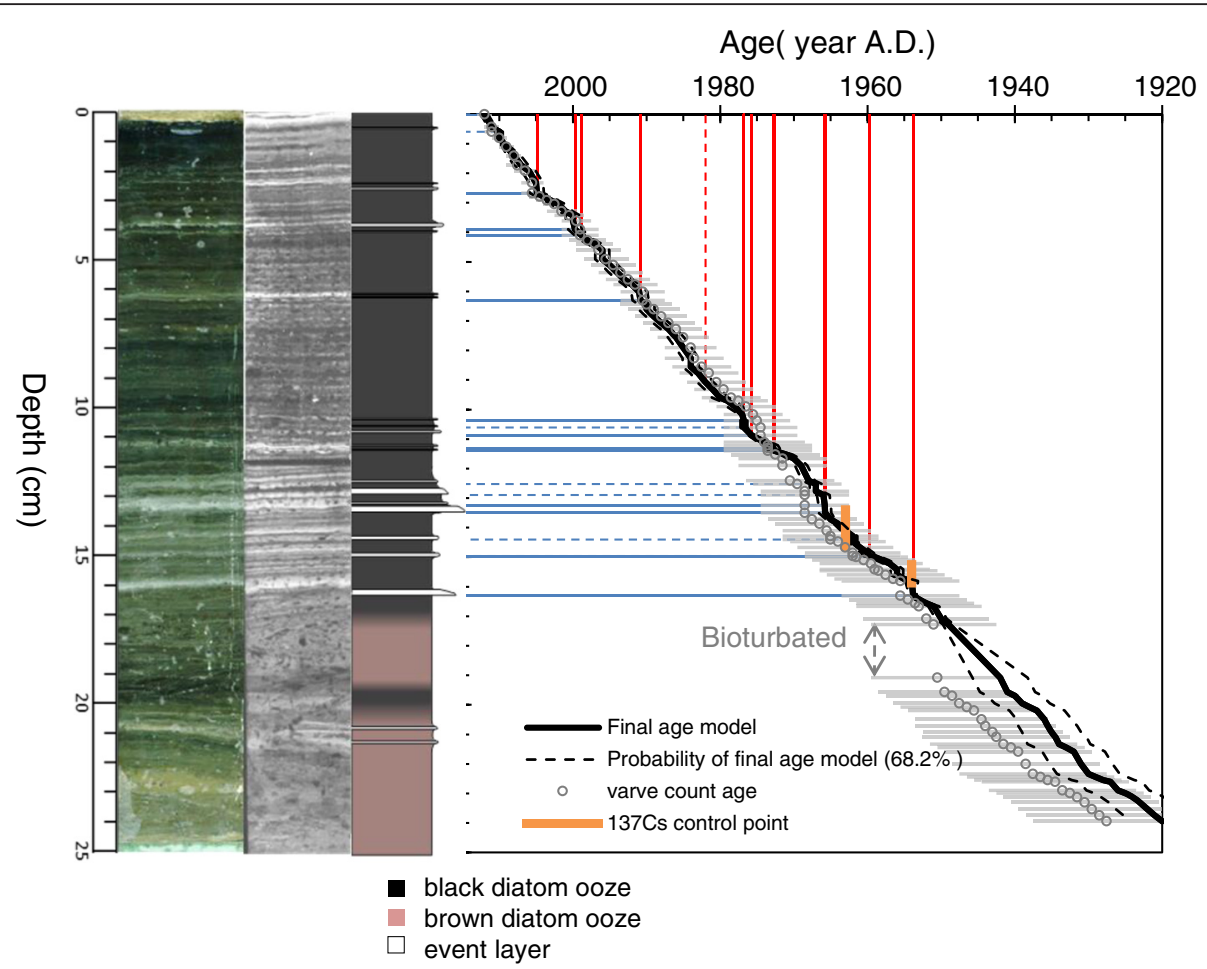

Fig. 3 Fine-tuned age model of SG12LM3 (black). Probability range (dashed lines) is estimated based on Bayesian analysis. Varve count age, ${ }^{137} \mathrm{CS}$ control points, and 12 pairs of event layers (blue solid lines) and historically recorded flood events (red solid lines) are also shown

neighboring age control points by counting unclear varves $(0.5 \pm 0.5$ years in the preliminary age model $)$ as $0 \pm 0,1 \pm 0$, or $0.5 \pm 0.5$ years (Additional file 1: Figure S1).

\section{Estimation of age uncertainty using a Bayesian approach}

To verify the reliability of the fine-tuned age model, we conducted Bayesian analysis on the basis of study by Bronk Ramsey (2009) using OxCal software (http://c14.arch.ox.ac.uk). We used sets of varve counts and their errors sandwiched by two neighboring control points (a set is called "si = sample interval", Additional file 1: Figure S2A, Additional file 2: Table S2) to estimate the age difference between centers of neighboring "si" using Bayesian analysis. In the analysis, varve counts and its errors are used as prior probability, and age of control points (Table 1) are used for constraints. The results (Additional file 1: Figure S2B, Additional file 2: Table S3) indicate that our estimations of the errors in ages for the fine-tuned age model are in agreement with the posterior probability estimates of the Bayesian analysis. Therefore, we verified the fine-tuned age model. We did not use a Bayesian age model because it does not provide annual resolution. For the error estimation, we adopted a probability estimation based on Bayesian analysis because it narrows the age estimation error (Additional file 2: Table S1).

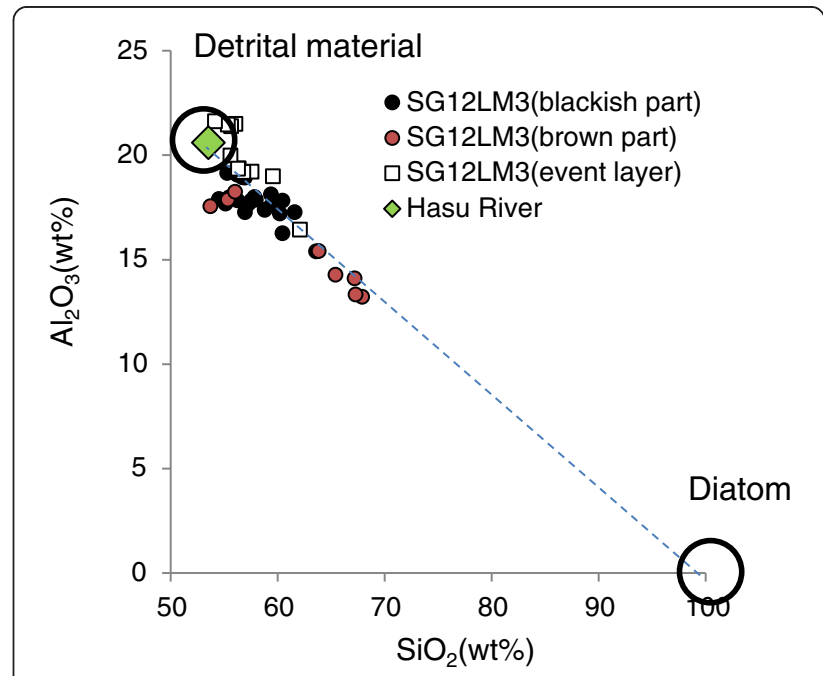

Fig. $4 X-Y$ plot of $\mathrm{SiO}_{2}$ and $\mathrm{Al}_{2} \mathrm{O}_{3}$ content for SG12LM3 samples and the Hasu River suspended material. Black circles represent the values of the Hasu River and diatom 
Table 2 XRF data of the SG12LM3 samples and suspended material from the Hasu River

\begin{tabular}{|c|c|c|c|c|c|c|c|c|c|c|c|c|c|c|c|}
\hline \multirow[b]{2}{*}{ SG12LM3 } & \multicolumn{2}{|c|}{ Distance from the core top $(\mathrm{cm})$} & \multicolumn{11}{|c|}{ XRF data (wt\%) } & \multirow[b]{2}{*}{$C_{\text {det }}(\mathrm{wt} \%)$} & \multirow[b]{2}{*}{$\mathrm{DBD}(\mathrm{g} / \mathrm{cm} 3)$} \\
\hline & Top & Bottom & LOI & $\mathrm{SiO}_{2}$ & $\mathrm{TiO}_{2}$ & $\mathrm{Al}_{2} \mathrm{O}_{3}$ & $\mathrm{Fe}_{2} \mathrm{O}_{3}$ & $\mathrm{MnO}$ & $\mathrm{MgO}$ & $\mathrm{CaO}$ & $\mathrm{Na}_{2} \mathrm{O}$ & $\mathrm{K}_{2} \mathrm{O}$ & $\mathrm{P}_{2} \mathrm{O}_{5}$ & & \\
\hline SG12LM3-02 & 0.5 & 1.1 & 33.40 & 62.09 & 0.77 & 16.45 & 7.74 & 0.10 & 3.15 & 1.02 & 4.49 & 3.54 & 0.63 & 41.78 & 0.12 \\
\hline SG12LM3-03 & 1.1 & 1.7 & 35.93 & 60.46 & 0.72 & 16.27 & 8.85 & 0.17 & 3.16 & 1.01 & 5.04 & 3.74 & 0.58 & 38.83 & 0.11 \\
\hline SG12LM3-04 & 1.7 & 2.2 & 28.14 & 59.41 & 0.84 & 17.60 & 9.64 & 0.21 & 3.13 & 0.92 & 4.56 & 3.29 & 0.40 & 47.28 & 0.13 \\
\hline SG12LM3-05 & 2.2 & 2.8 & 27.97 & 61.60 & 0.81 & 17.27 & 8.18 & 0.21 & 2.99 & 0.91 & 4.44 & 3.17 & 0.42 & 47.63 & 0.14 \\
\hline SG12LM3-06 & 2.8 & 3.4 & 27.67 & 56.96 & 0.77 & 18.93 & 10.50 & 0.23 & 3.02 & 0.91 & 5.28 & 3.03 & 0.38 & 50.43 & 0.13 \\
\hline SG12LM3-07 & 3.4 & 4 & 24.01 & 56.06 & 0.90 & 21.51 & 9.57 & 0.26 & 2.96 & 0.83 & 4.35 & 3.18 & 0.37 & 61.53 & 0.16 \\
\hline SG12LM3-08 & 4 & 4.6 & 34.20 & 57.54 & 0.83 & 17.83 & 9.02 & 0.23 & 3.53 & 1.30 & 5.28 & 4.02 & 0.41 & 42.93 & 0.11 \\
\hline SG12LM3-09 & 4.6 & 5.2 & 29.43 & 60.21 & 0.79 & 17.22 & 9.07 & 0.23 & 3.02 & 1.01 & 4.80 & 3.28 & 0.38 & 45.66 & 0.14 \\
\hline SG12LM3-10 & 5.2 & 5.8 & 26.25 & 58.81 & 0.80 & 17.39 & 10.32 & 0.23 & 3.06 & 0.91 & 5.11 & 3.05 & 0.32 & 47.43 & 0.15 \\
\hline SG12LM3-11 & 5.8 & 6.4 & 22.63 & 59.57 & 0.86 & 19.00 & 9.43 & 0.21 & 3.00 & 0.79 & 3.93 & 2.94 & 0.27 & 56.08 & 0.18 \\
\hline SG12LM3-12 & 6.4 & 7 & 26.25 & 60.46 & 0.80 & 17.83 & 8.27 & 0.23 & 3.02 & 0.87 & 4.94 & 3.27 & 0.30 & 49.98 & 0.16 \\
\hline SG12LM3-13 & 7 & 7.6 & 27.91 & 57.97 & 0.81 & 17.87 & 10.54 & 0.30 & 3.01 & 0.91 & 4.87 & 3.38 & 0.33 & 47.43 & 0.13 \\
\hline SG12LM3-14 & 7.6 & 8.2 & 28.25 & 56.94 & 0.80 & 17.28 & 10.64 & 0.33 & 3.16 & 1.19 & 5.75 & 3.61 & 0.31 & 44.66 & 0.13 \\
\hline SG12LM3-15 & 8.2 & 8.9 & 24.33 & 59.39 & 0.84 & 18.13 & 9.25 & 0.32 & 2.94 & 0.86 & 4.61 & 3.37 & 0.29 & 51.64 & 0.13 \\
\hline SG12LM3-16 & 8.9 & 9.5 & 24.61 & 57.85 & 0.87 & 18.01 & 10.64 & 0.36 & 3.05 & 0.94 & 4.90 & 3.10 & 0.28 & 49.99 & 0.15 \\
\hline SG12LM3-17 & 9.5 & 10.1 & 28.22 & 56.25 & 0.88 & 17.84 & 10.89 & 0.37 & 3.14 & 1.05 & 5.77 & 3.46 & 0.36 & 46.06 & 0.14 \\
\hline SG12LM3-18 & 10.1 & 10.7 & 24.45 & 56.37 & 0.88 & 19.38 & 10.90 & 0.39 & 2.95 & 0.83 & 4.62 & 3.36 & 0.32 & 53.82 & 0.16 \\
\hline SG12LM3-19 & 10.7 & 11.3 & 21.70 & 55.61 & 0.95 & 19.98 & 11.31 & 0.39 & 3.08 & 1.02 & 4.29 & 3.05 & 0.31 & 57.43 & 0.19 \\
\hline SG12LM3-20 & 11.3 & 11.9 & 22.66 & 56.21 & 0.95 & 19.08 & 11.57 & 0.40 & 3.14 & 0.97 & 4.45 & 2.94 & 0.29 & 53.94 & 0.17 \\
\hline SG12LM3-21 & 11.9 & 12.55 & 20.54 & 57.57 & 0.98 & 19.23 & 11.35 & 0.39 & 3.04 & 0.81 & 3.47 & 2.83 & 0.33 & 56.95 & 0.20 \\
\hline SG12LM3-22 & 12.55 & 13.1 & 17.01 & 55.66 & 1.05 & 21.39 & 11.28 & 0.35 & 3.13 & 0.74 & 3.34 & 2.77 & 0.29 & 66.41 & 0.23 \\
\hline SG12LM3-23 & 13.1 & 13.7 & 17.96 & 55.37 & 1.02 & 21.47 & 11.37 & 0.36 & 3.10 & 0.79 & 3.42 & 2.80 & 0.31 & 65.70 & 0.24 \\
\hline SG12LM3-24 & 13.7 & 14.3 & 20.40 & 56.80 & 1.00 & 19.20 & 11.84 & 0.50 & 3.19 & 0.82 & 3.60 & 2.79 & 0.26 & 56.39 & 0.21 \\
\hline SG12LM3-25 & 14.3 & 14.95 & 20.36 & 56.31 & 1.00 & 19.37 & 11.92 & 0.57 & 3.17 & 0.82 & 3.74 & 2.83 & 0.27 & 56.66 & 0.21 \\
\hline SG12LM3-26 & 14.95 & 15.55 & 23.79 & 56.72 & 0.93 & 18.96 & 11.44 & 0.65 & 3.07 & 0.91 & 4.00 & 3.03 & 0.30 & 53.07 & 0.20 \\
\hline SG12LM3-27 & 15.55 & 16.2 & 19.77 & 54.14 & 1.01 & 21.63 & 12.26 & 0.65 & 3.00 & 0.74 & 3.34 & 2.93 & 0.31 & 63.82 & 0.22 \\
\hline SG12LM3-28 & 16.2 & 16.7 & 25.15 & 55.31 & 0.93 & 19.15 & 12.61 & 0.74 & 3.02 & 0.88 & 4.06 & 2.96 & 0.35 & 51.80 & 0.19 \\
\hline SG12LM3-29 & 16.7 & 17.3 & 26.46 & 54.52 & 0.88 & 17.91 & 14.33 & 0.76 & 2.96 & 0.95 & 4.31 & 3.03 & 0.36 & 46.30 & 0.18 \\
\hline SG12LM3-30 & 17.3 & 17.9 & 27.41 & 55.49 & 0.89 & 17.99 & 13.01 & 0.69 & 3.02 & 1.12 & 4.24 & 3.04 & 0.49 & 46.59 & 0.18 \\
\hline SG12LM3-31 & 17.9 & 18.55 & 27.45 & 55.36 & 0.89 & 17.88 & 13.49 & 0.64 & 3.02 & 0.91 & 4.58 & 2.88 & 0.35 & 46.13 & 0.17 \\
\hline SG12LM3-32 & 18.55 & 19.2 & 28.59 & 53.72 & 0.86 & 17.57 & 14.68 & 0.64 & 3.03 & 0.88 & 5.05 & 3.22 & 0.35 & 43.42 & 0.17 \\
\hline SG12LM3-33 & 19.2 & 19.75 & 28.11 & 55.15 & 0.88 & 17.69 & 14.22 & 0.60 & 2.95 & 0.88 & 4.35 & 2.94 & 0.34 & 44.96 & 0.18 \\
\hline SG12LM3-34 & 19.75 & 20.4 & 25.61 & 57.31 & 0.89 & 17.69 & 12.96 & 0.47 & 2.85 & 0.80 & 4.05 & 2.66 & 0.33 & 47.92 & 0.19 \\
\hline SG12LM3-35 & 20.4 & 21 & 24.26 & 63.60 & 0.77 & 15.40 & 10.54 & 0.34 & 2.48 & 0.66 & 3.56 & 2.36 & 0.28 & 44.72 & 0.20 \\
\hline SG12LM3-36 & 21 & 21.6 & 21.17 & 67.21 & 0.71 & 14.10 & 9.14 & 0.27 & 2.26 & 0.58 & 3.29 & 2.20 & 0.24 & 43.89 & 0.21 \\
\hline SG12LM3-37 & 21.6 & 22.2 & 19.12 & 67.91 & 0.67 & 13.23 & 9.58 & 0.25 & 2.17 & 0.57 & 3.44 & 1.95 & 0.24 & 42.14 & 0.22 \\
\hline SG12LM3-38 & 22.2 & 22.7 & 21.99 & 67.29 & 0.67 & 13.33 & 9.68 & 0.24 & 2.16 & 0.58 & 3.42 & 2.38 & 0.25 & 40.70 & 0.22 \\
\hline SG12LM3-39 & 22.7 & 23.3 & 21.60 & 56.03 & 0.91 & 18.25 & 13.17 & 0.52 & 3.00 & 0.83 & 4.15 & 2.84 & 0.31 & 51.60 & 0.20 \\
\hline SG12LM3-40 & 23.3 & 23.9 & 21.16 & 63.84 & 0.78 & 15.43 & 10.37 & 0.30 & 2.45 & 0.65 & 3.44 & 2.48 & 0.27 & 46.80 & 0.21 \\
\hline SG12LM3-41 & 23.9 & 24.5 & 21.63 & 65.43 & 0.73 & 14.29 & 10.22 & 0.28 & 2.32 & 0.62 & 3.51 & 2.34 & 0.26 & 43.34 & 0.22 \\
\hline \multicolumn{16}{|l|}{ Hasu River } \\
\hline SG121001-01 & - & - & 16.20 & 53.53 & 1.55 & 20.61 & 13.41 & 0.53 & 3.98 & 1.83 & 1.62 & 2.33 & 0.60 & - & - \\
\hline
\end{tabular}




\section{Estimation of detrital flux}

The flux of detrital material $\left(F_{\text {det }}, \mathrm{mg} / \mathrm{cm}^{2} /\right.$ year $)$ for each sample was calculated using Eq. (2) to compare with observational precipitation record of this region to examine the relationship between $F_{\text {det }}$ and precipitation

$$
F_{\mathrm{det}}=\mathrm{DBD} \times \mathrm{SR} \times C_{\mathrm{det}},
$$

where DBD $\left(\mathrm{g} / \mathrm{cm}^{3}\right)$ is the dry bulk density estimated from GD and WC, SR is the sedimentation rate $(\mathrm{cm} /$ year) based on the fine-tuned age model, and $C_{\mathrm{det}}$ is the weight fraction of detrital material in the sample. The water content (WC, in weight fraction) was calculated on the basis of the dry $\left(W_{\mathrm{d}}\right)$ and wet $\left(W_{\mathrm{w}}\right)$ weights of the sample, and DBD was calculated from WC and grain density $\left(\mathrm{GD}, \mathrm{g} / \mathrm{cm}^{3}\right) . C_{\text {det }}$ (wt\%) was estimated on the basis of the $\mathrm{Al}_{2} \mathrm{O}_{3}$ and $\mathrm{SiO}_{2}$ contents of each sample determined by XRF. The contents of $\mathrm{Al}_{2} \mathrm{O}_{3}$ and $\mathrm{SiO}_{2}$ were negatively correlated and mostly plotted on a line between the point of $\left(\mathrm{SiO}_{2}, \mathrm{Al}_{2} \mathrm{O}_{3}\right)=(100$ (wt\%), 0), which represents biogenic silica, and (53.5, 20.6), which represents suspended material from the Hasu River (Fig. 4). These results are consistent with the idea that the suspended material from the Hasu River is the major source of the detrital material. Thus, we assumed that the
$\mathrm{Al}_{2} \mathrm{O}_{3}$ and $\mathrm{SiO}_{2}$ contents of the samples represent a mixing ratio of diatom frustules and suspended detrital material from the Hasu River. Moreover, we estimated the concentration of the suspended material originating from the Hasu River for each sample on the basis of the equation

$$
C_{\text {det }}=\left(\mathrm{Al}_{2} \mathrm{O}_{3}+\mathrm{SiO}_{2}\right) \times \frac{\mathrm{Al}_{2} \mathrm{O}_{3}}{20.6} \times \frac{100-\mathrm{LOI}}{100}
$$

where $\mathrm{Al}_{2} \mathrm{O}_{3}$ and $\mathrm{SiO}_{2}$ are the concentrations (in wt\%) in each ignited sample measured by XRF (Fig. 4). The XRF data, $C_{\text {det }}$, and DBD of SG12LM3 are listed in Table 2. The profiles of $C_{\text {det }}$, SR, DBD, and $F_{\text {det }}$ of a sample are shown in Fig. 5. The values of $C_{\text {det }}$ are higher (ca. $60 \%)$ in samples that contain event layers compared to other samples with $C_{\mathrm{det}}=40$ to $50 \%$; the latter samples were considered to represent background sedimentation. The sedimentation rate $(\mathrm{cm} /$ year) tended to be higher $(\sim 0.7 \mathrm{~cm} /$ year$)$ in samples containing event layers and lower in other samples $(\sim 0.2 \mathrm{~cm} /$ year $)$. DBD showed a decreasing trend from the top of the core $\left(\sim 0.1 \mathrm{~g} / \mathrm{cm}^{3}\right)$ to the bottom $\left(\sim 0.25 \mathrm{~g} / \mathrm{cm}^{3}\right)$, primarily due to increasing compaction. The DBD values also tended to be higher in samples containing event layers $\left(\sim 0.25 \mathrm{~g} / \mathrm{cm}^{3}\right)$.

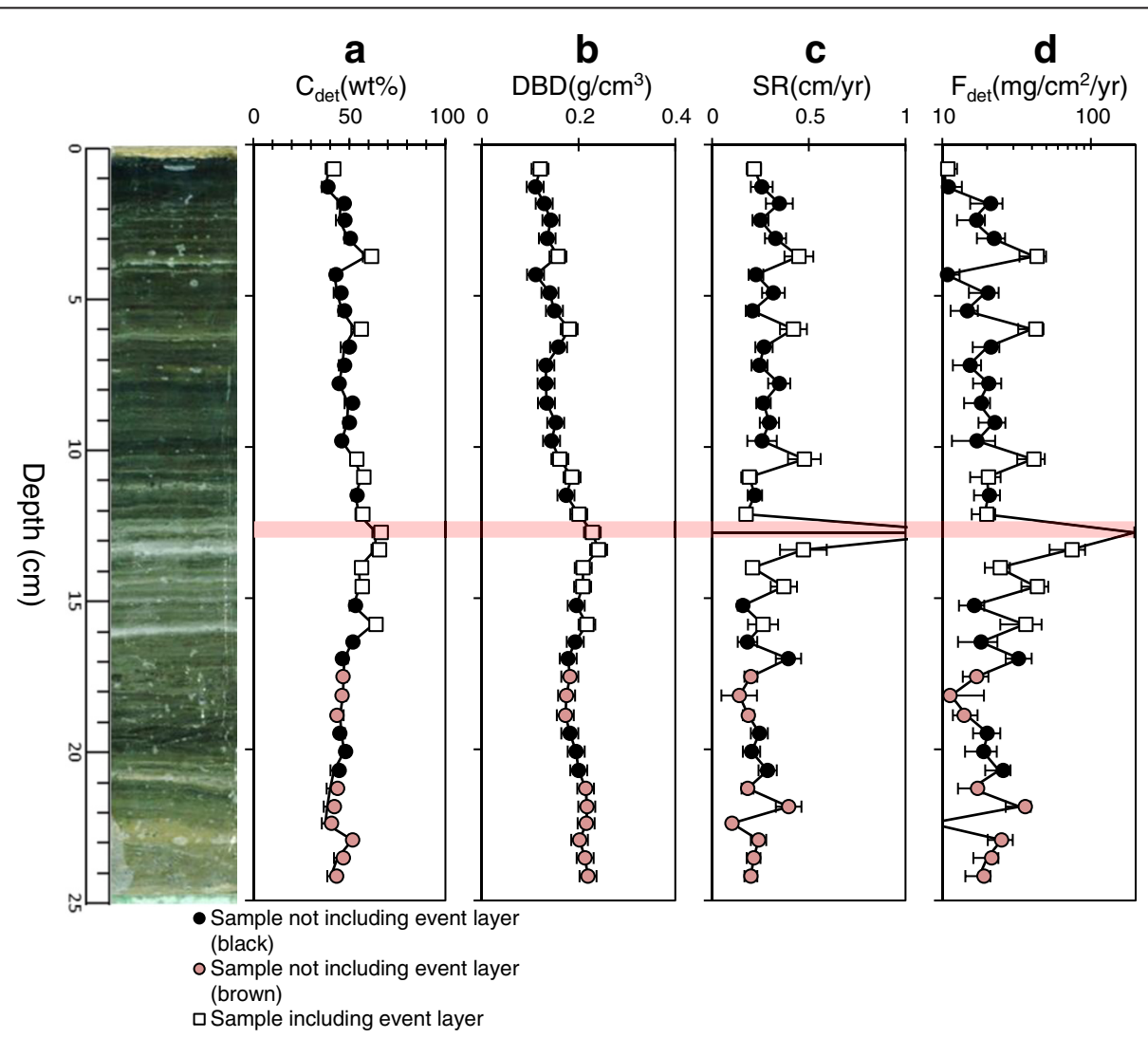

Fig. 5 Depth profiles of the $(A)$ weight fraction of detrital material $\left(C_{\text {det }}\right)$ and $(B)$ Dry bulk density $(D B D)$, $(C)$ sedimentation rate $(S R)$, and $(D)$ flux of detrital material $\left(F_{\text {det }}\right)$ of SG12LM3. The sample which interval is less than 1 year is shown with red shade 


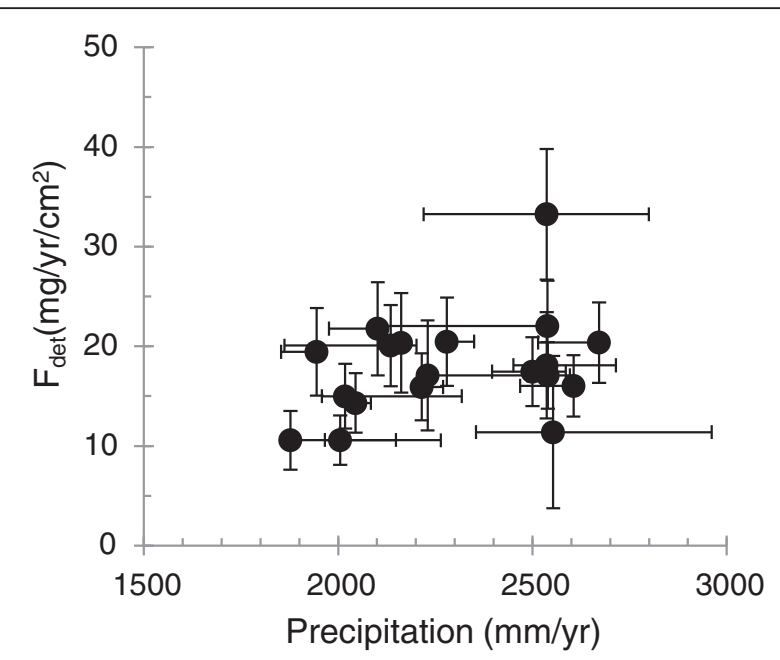

Fig. $6 \mathrm{X}-\mathrm{Y}$ plot of the annual precipitation (excluding $>100 \mathrm{~mm} /$ day) [JMA, http://www.data.jma.go.jp/gmd/risk/obsdl/index.php] and corresponding detrital flux of SG12LM3 background sedimentation samples (excluding the samples including event layers). The detrital flux shows a weak positive relationship with the annual precipitation
$F_{\text {det }}$ varied widely from 10 to $\sim 100 \mathrm{mg} / \mathrm{cm}^{2} /$ year (Fig. 5D); in samples including event layers, $F_{\text {det }}$ shows maxima ranged from 10 to $100 \mathrm{mg} / \mathrm{cm}^{2} /$ year, whereas it ranged from $10 \sim 35 \mathrm{mg} / \mathrm{cm}^{2} /$ year in samples not including event layers. $F_{\text {det }}$ reached the maximum at 1965 A.D., when this region received over $400 \mathrm{~mm}$ of continuous precipitation within 1 week; this was the most significant precipitation event in the past 100 years and was caused by two typhoons that directly hit the area. The variations in $F_{\text {det }}$ were closely associated with SR, suggesting that SR (nearly equal to the varve thickness (+ event layers)) had a stronger effect on $F_{\text {det }}$ than $C_{\text {det }}$ or DBD. The samples with an extremely short interval (less than 1 year) were excluded in the following discussion because of the large estimation error of the $F_{\text {det }}$ due to the large uncertainty of the SR (SG12LM3-22, depth $=12.55$ to $13.1 \mathrm{~cm}$, red shaded in Fig. 5). The flux of total detrital material calculated here was 5- to 10-times larger than the eolian dust fluxes in SW Honshu and the south-central part of the Sea of Japan, which were estimated as less than $2 \mathrm{mg} / \mathrm{cm}^{2} /$ year by observation [Osada et al. 2014] and analysis of sediment core

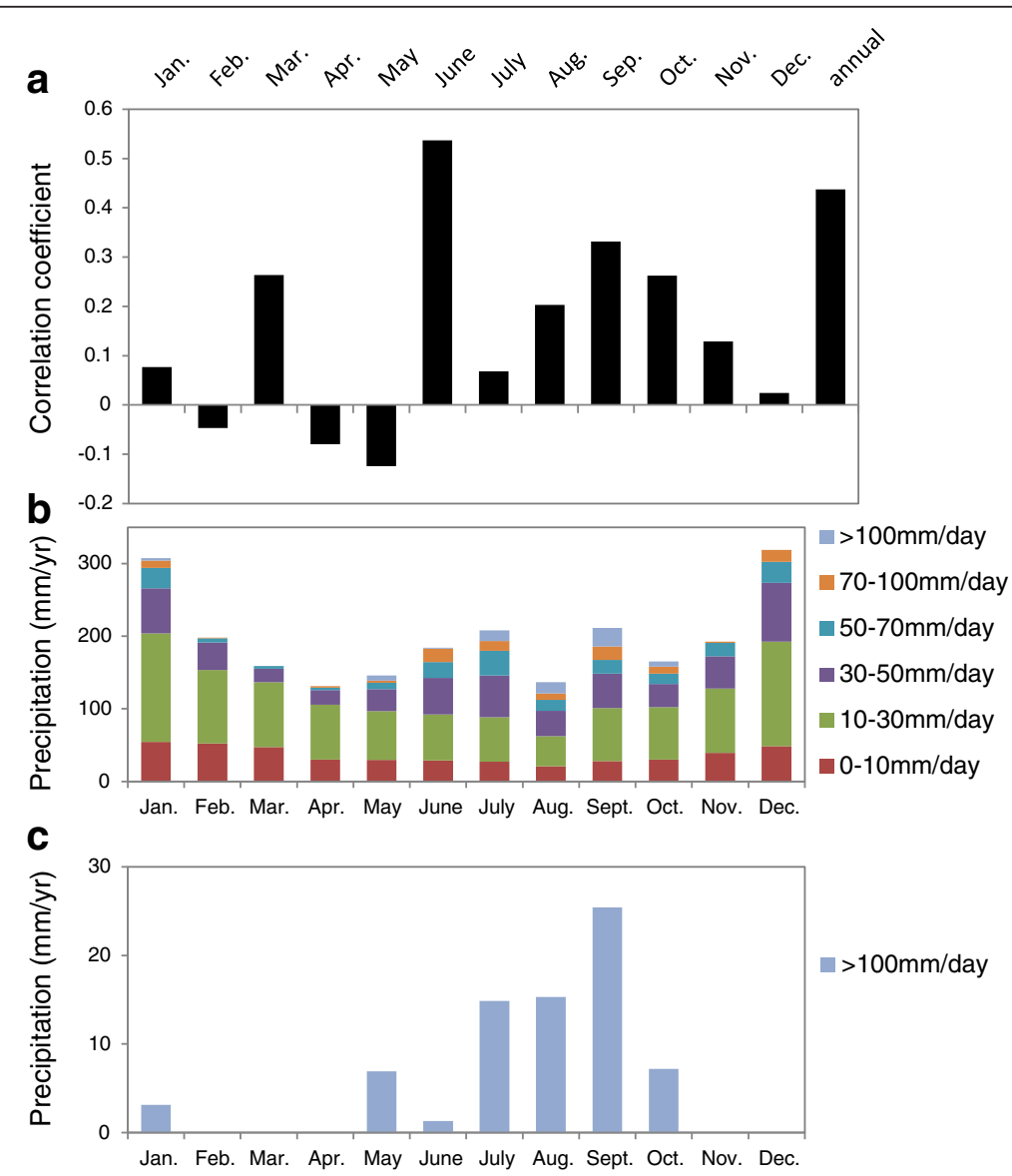

Fig. 7 a Linear regression correlation coefficients $(R)$ of $F_{\text {det }}$ with monthly and annual precipitation amounts (excluding $>100 \mathrm{~mm} /$ day). b Monthly precipitation summed up at each category (mm/day) observed at the Tsuruga observatory averaged from 1937 to 2012. c Same as (b) but for the monthly precipitation, larger than $100 \mathrm{~mm}$ per day 


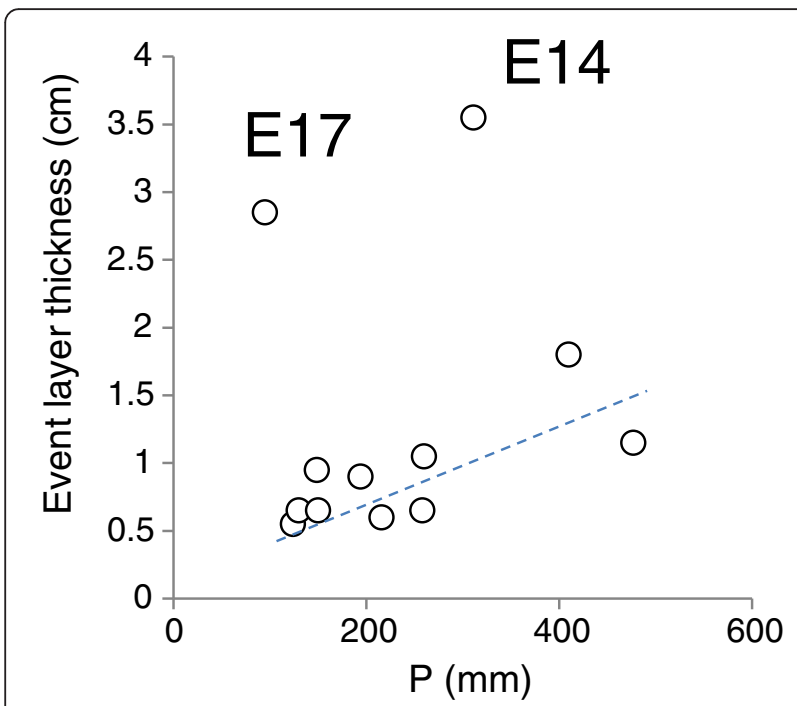

Fig. 8 The relationship between the total precipitation during historical floods and the thickness of the corresponding event layers
[Irino and Tada 2000; Nagashima et al. 2007], respectively. Therefore, herein, we did not separate the contribution of eolian dust.

\section{Results and discussion \\ Relationship between detrital flux and precipitation in Lake Suigetsu}

We investigated the relationship between $F_{\operatorname{det}}$ and observed precipitation in the study region, which we expected to be exponentially related. Here, we only discuss samples that do not include event layers. The relationship between the event layers and precipitation causing flooding is discussed in "Relationship of event layers and flood events". Figure 6 shows a plot of mean annual precipitation for each sample and $F_{\text {det }}$. Mean annual precipitation was estimated on the basis of the ages of the top and bottom of each sample and the precipitation record from Tsuruga observatory $(20 \mathrm{~km}$ NE of Lake Suigetsu; Fig. 1b) [obtained from Japan Meteorological Agency, http://www.data.jma.go.jp/gmd/ risk/obsdl/index.php].

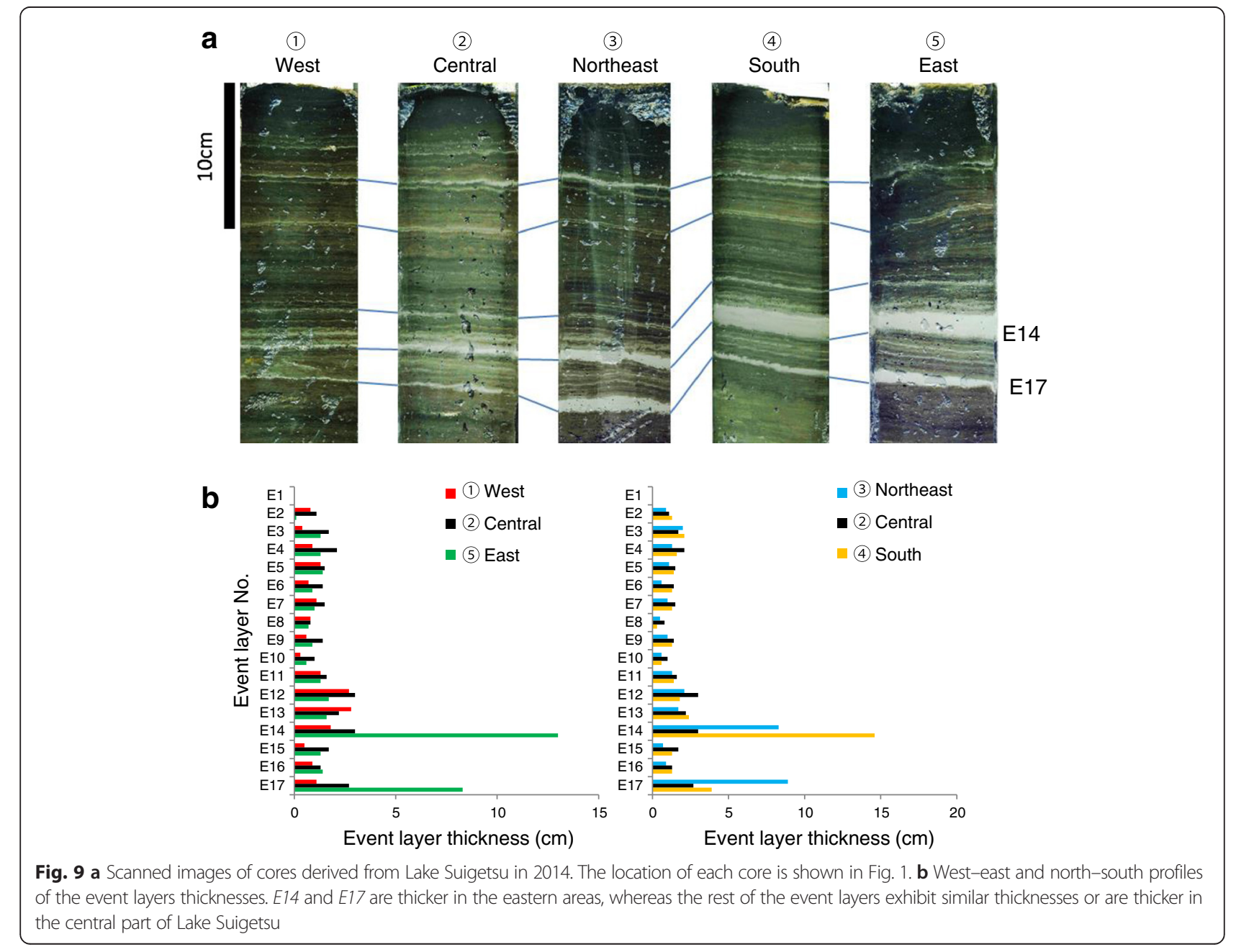


The $F_{\text {det }}$ values of samples without event layers showed a weak positive correlation $(R=0.43)$ with annual precipitation. However, except for one sample characterized by high precipitation and high $F_{\text {det }}$ values, the correlation is not so clear.

To examine the influence of seasonal precipitation on the $F_{\text {det }}$ of background sedimentation (excluding event layers), we also examined the correlation between monthly precipitation and $F_{\text {det }}$. As is shown in Fig. 7a, the correlation coefficients have the highest value $(R=0.54)$ in June, known as the Baiu season (Japanese rainy season) and characterized by frequent heavy precipitation exceeding $30 \mathrm{~mm}$ (Fig. 7b). In addition, the correlation coefficients have relatively higher values in September $(R=0.33)$, known as typhoon season, also characterized by frequent heavy precipitation (Fig. 7b). This result suggests that $F_{\text {det }}$ in the background sediment is rather sensitive to the precipitation in certain season when strong river discharge is expected. We will further investigate the relationship between suspended particles in the Hasu River and precipitation by conducting turbidity measurements in the Hasu River.

\section{Relationship of event layers and flood events}

The event layers, characterized by detrital flux maxima, could directly correlate to the historically recorded floods. Then, we further examined the relationship between event layer thickness and total precipitation associated with the historically recorded flood events to test whether the event layers record intensity of the extreme precipitation. Figure 8 shows plots of event layer thickness versus cumulative precipitation amount during a flood event. We observed a strong positive linear relationship (thickness of event layer $(\mathrm{mm})=0.34+0.0023 \times($ precipitation: $\mathrm{mm}) ; R=0.74)$ for all event layers except E14 and E17, which are exceptionally thick ( 2.85 and $3.5 \mathrm{~mm}$, respectively). Based on the relation, we examined whether the characteristics of these two event layers E14 and E17 are distinctly different from those of the other layers. Based on the scanned images of half-split cores of near-surface sediments obtained from different parts of the lake (Fig. 9a), the thicknesses of event layers were similar throughout the lake, with the exceptions of layers E14 and E17 (Fig. 9b). This suggests that most of the event layers were deposited from a suspended sediment cloud that spread homogeneously all over the lake. However, the thicknesses of event layers E14 and E17 vary significantly within the lake, indicating that E14 and E17 include large amounts of detrital materials that were directly supplied from the slopes surrounding the lake.

The number of typhoons that hit Japan without causing flooding is much greater than that of causing flood events in the study area. To characterize typhoons that cause flood recorded as event layers in Lake Suigetsu

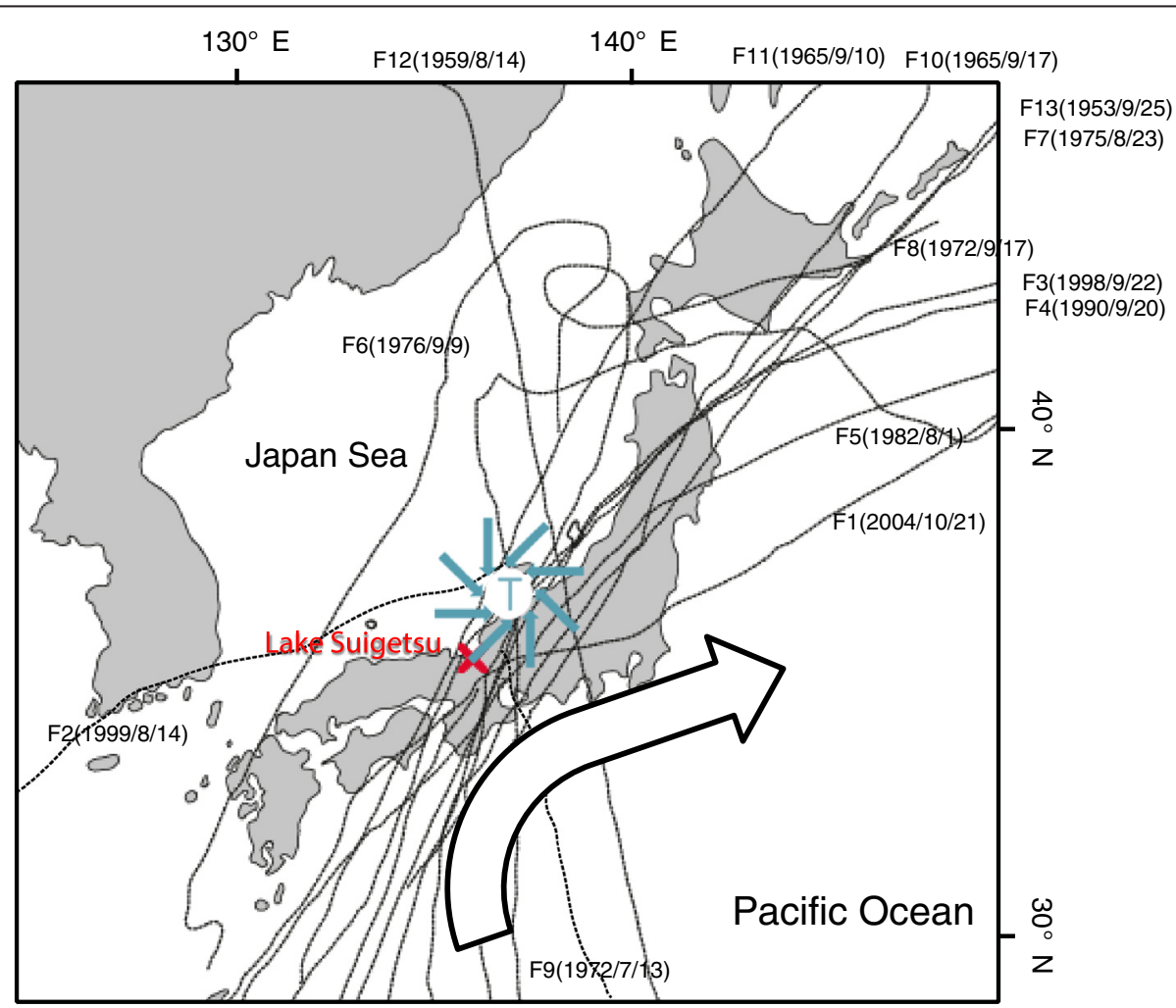

Fig. 10 Routes of typhoons (dashed lines), which caused historically recorded floods in the area around Lake Suigetsu. Schematic track of a general typhoon (not generating flood around Lake Suigetsu) is shown as an arrow 
sediments, we summarized the routes of typhoons corresponding to F1, 3-8, 10-13 of Table 1 (Fig. 10). These typhoons which caused floods hit the middle part of Honshu Island then moved to the north, passing through the western side of the island. Because typhoons are known to gain vapor from areas neighboring the typhoon center [Fudeyasu et al. 2008], typhoons taking such a route should have received vapor from the Japan Sea, enabling them to cause heavy precipitation on the Japan Sea side of the island. In contrast, typhoons that did not cause flooding around Lake Suigetsu passed through the southern and eastern sides of Honshu Island. Furthermore, event layers were deposited only when total precipitation exceeded $\sim 100 \mathrm{~mm}$ (Table 1, Fig. 8). As shown in Fig. 7c, precipitation exceeding $100 \mathrm{~mm} /$ day occurs mainly in the typhoon season and a little in Baiu seasons. These results indicate that event layers were deposited during strong precipitation, primarily precipitation caused by approaching typhoons and thickened with increasing precipitation.

\section{Conclusions}

A highly precise age model of the near-surface sediments of Lake Suigetsu was established on the basis of varve counting combined with a verification of the age estimation using excess ${ }^{210} \mathrm{~Pb}$ and ${ }^{137} \mathrm{Cs}$ dating. The model was finetuned by correlating event layers and observed flood events. Using sedimentation rates calculated from the developed age model, XRF data, and dry bulk density data, the flux of detrital material was reconstructed with a resolution of 2-3 years. The estimated detrital flux of background sedimentation showed a weak positive correlation with annual and monthly (June and September) precipitation excluding heavy precipitation that exceeded $100 \mathrm{~mm} /$ day. Furthermore, event layer thickness corresponded to the maxima of detrital flux was positively related to the total amount of precipitation during a flood event [(thickness of event layer: $\mathrm{mm})=0.34+0.0023 \times($ precipitation: $\mathrm{mm}) ; R=0.74]$. These results indicate that the detrital flux maxima (deposition of event layers) record the occurrence and magnitude of flood events caused by typhoons. The typhoons that trigger event layer deposition tend to pass through the northwest part of Honshu Island, where they receive an abundant vapor supply from the Sea of Japan.

\section{Additional files}

Additional file 1: Figure S1. A typical case of recognition, classification, and counting of varves. Red lines are clear varves showing moderate $(\sim 100)$ peaks with moderate gradient $(5 \sim 10)$ in gray scale. Gray lines are event layers showing high (>100) peaks with high gradient (10 30) in gray scale. Yellow lines are unclear varves (counted as $0 \sim 1$ year) showing low peaks in gray scale or not horizontally continuous. Figure S2. (A) Sample intervals of SG12LM3 used for Bayesian analysis and (B) estimated age differences between the centers of neighboring sample intervals using
Bayesian analysis. Open and close ranges show probabilities of age differences based on varve counting and its coupling with Bayesian analysis, respectively. (PPTX $550 \mathrm{~kb}$ )

Additional file 2: Table S1. Varve count age model and fine-tuned age model with distance from the core top of SG12LM3 core. Table S2. List of top and bottom age, varve count, and its error of each "si" input as prior probability of Bayesian analysis. Table S3. List of age differences for SG12LM3 estimated by Bayesian analysis. (XLSX $18 \mathrm{~kb}$ )

\section{Competing interests}

The authors declare that they have no competing interests.

\section{Authors' contributions}

YS collected the samples, conducted the XRF measurements, established the age-depth model, and wrote the paper as a part of his doctoral thesis work under the supervision of RT. RT designed and directed the project, helped collect the samples, and established the age-depth model. KY conducted coring in July 2012 and showed YS the coring technique in June 2014. TI conducted the measurements of the $\mathrm{Pb}$ and $\mathrm{Cs}$ isotopes and helped with the sample pretreatment. KN collected the water samples in October 2012 and helped establish the age-depth model. TN helped collect the samples and establish the age-depth model. TO conducted the Bayesian analysis of the age model. All authors read and approved the manuscript.

\section{Acknowledgements}

We would like to express our thanks to SG12 project members, the drilling team of Seibushisui Co. Ltd., and staffs at Jomon Museum in Wakasa town for sampling and safekeeping during the collection of SG12LM cores. Mr. Kojima in Jomon Museum gave us compiled data of historical floods in Wakasa town. We also thank Dr. Ashi and Dr. Omura of AORI, University of Tokyo, for allowing us to use the He pycnometer. Dr. Yoshida and Mr. Kobayashi of the University of Tokyo helped us operate the XRF spectrometer. The authors would like to thank Enago (www.enago.jp) for the English language review. This research is supported by the JSPS KAKENHI Grant KIBAN-S Number 23221002.

\section{Author details}

${ }^{1}$ Department of Earth and Planetary Sciences, Graduate School of Science, University of Tokyo, 7-3-1 Hongo Bunkyo-ku, Tokyo, Japan. ${ }^{2}$ Museum of Natural and Environmental History, Shizuoka, Japan. ${ }^{3}$ Faculty of Environmental Earth Science, Hokkaido University, Sapporo, Japan. ${ }^{4}$ Research Institute for Global Change, Japan Agency for Marine-Earth Science and Technology (JAMSTEC), Yokosuka, Japan. ${ }^{5}$ Research Center for Palaeoclimatology, Ritsumeikan University, Kusatsu, Japan. ${ }^{6}$ The University Museum, The University of Tokyo, Tokyo, Japan.

Received: 23 July 2015 Accepted: 18 January 2016

Published online: 12 February 2016

\section{References}

\section{Compilation of flood record}

Looking back the history of Mikata-Town, PR magazine of Mikata-Town, 2005

Memoric magazine of $50^{\text {th }}$ anniversary of Kaminaka-Town organization, Center of Kaminaka-Town residents, 2004

Mikata Town History. Editing committee of Mikata-Town history. 1990. Books and Papers

Arnell NW (1992) Factors controlling the effects of climate change on river flow regimes in a humid temperate environment. J Hydrol 132(1):321-42

Delaune RD et al (1978) Sedimentation rates determined by 137Cs dating in a rapidly accreting salt marsh. Nature 275(5680):532-3. doi:10.1038/275532a0

Fudeyasu $\mathrm{H}$, et al. Isotope ratios of precipitation and water vapor observed in Typhoon Shanshan. J. Geophys. Res. 2008;113(D12113). doi:10.1029/ 2007JD009313

Fukusawa $\mathrm{H}$ et al (1994) Historical earthquake, flood and human activity events recorded in the Holocene sediments of Lake Suigetsu, Fukui Prefecture, central Japan. J Geog 103(2):127-39

Irino T, Tada R (2000) Quantification of aeolian dust (Kosa) contribution to the Japan Sea sediments and its variation during the last 200 ky. Geochem J 34:59-93 
Kaji J, Nihei Y (2014) Evaluation of freshwater discharge and suspended sediment transport into pacific ocean from Tohoku and Kanto districts. JCSE 70(4):979-84

Kansanen PH et al (1991) Sedimentation and distribution of gamma-emitting radionuclides in bottom sediments of southern Lake Paijanne, Finland, after the Chernobyl accident. Hydrobiologia 222(2):121-40. doi:10.1007/ BF00006100

Kato Y et al (2003) 210Pb and 137Cs in sediments from Sagami Bay, Japan: sedimentation rates and inventories. Prog Oceanogr 57(1):77-95. doi:10.1016/S0079-6611(03)00052-1

Kazama $S$ et al (2005) Estimation of rating-curve parameters for sedimentation using a physical model. Hydrol Process 19(19):3863-71. doi:10.1002/hyp.5986

Marshall M et al (2012) A novel approach to varve counting using MXRF and Xradiography in combination with thin-section microscopy, applied to the late glacial chronology from Lake Suigetsu. Japan Quat Geochronol 13:70-80. doi: 10.1016/j.quageo.2012.06.002

Milliman JD, Syvitski JPM (1992) Geomorphic/Tectonic Control of Sediment Discharge to the Ocean: The Importance of Small Mountainous Rivers. J Geol 100:525-544

Nagashima K et al (2007) Orbital-and millennial-scale variations in Asian dust transport path to the Japan Sea. Palaeogeogr Palaeoclimatol Palaeoecol 247:144-61

Nakagawa T et al (2002) Quantitative pollen-based climate reconstruction in central Japan: application to surface and Late Quaternary spectra. Quat Sci Rev 21(18-19):2099-113. doi:10.1016/S0277-3791(02)00014-8

Nakagawa T et al (2005) Pollen/event stratigraphy of the varved sediment of Lake Suigetsu, central Japan from 15,701 to 10,217 SG vyr BP (Suigetsu varve years before present): Description, interpretation, and correlation with other regions. Quaternary Science Reviews 24(14-15):1691-1701. doi:10.1016/j.quascirev.2004.06.022

Nakagawa T et al (2012) SG06, a fully continuous and varved sediment core from Lake Suigetsu, Japan: stratigraphy and potential for improving the radiocarbon calibration model and understanding of late Quaternary climate changes. Quat Sci Rev 36:164-76. doi:10.1016/j.quascirev.2010.12.013

Osada K et al (2014) Wet and dry deposition of mineral dust particles in Japan: factors related to temporal variation and spatial distribution. Atmos Chem Phys 14(2):1107-21. doi:10.5194/acp-14-1107-2014

Ramsey CB (2009) Bayesian analysis of radiocarbon dates. Radiocarbon 51(1): 337-60. doi:10.2458/azu_js_rc.v51i1.3494

Ramsey C et al (2012) A complete terrestrial radiocarbon record for 11.2 to 52.8 kyr B.P. Science 338(6105):370-4. doi:10.1126/science.1226660

Ramsey CB et al (2013) An assessment of the magnitude of the AD1586 Tensho tsunami inferred from Lake Suigetsu sediment cores. J Geogr (Chigaku Zasshi) 122(3):493-501. doi:10.5026/jgeography.122.493

Sadeghi SHR et al (2008) Development, evaluation and interpretation of sediment rating curves for a Japanese small mountainous reforested watershed. Geoderma 144(1-2):198-211. doi:10.1016/j.geoderma.2007.11.008

Saito-Kato M et al (2013) An Assessment of the Magnitude of the AD1586 Tensho Tsunami Inferred from Lake Suigetsu Sediment Cores. Journal of Geography (Chigaku Zasshi) 122(3):493-501. doi:10.5026/jgeography.122.493

Schillereff D et al (2014) Flood stratigraphies in lake sediments: a review. Earth Sci Rev 135:17-37

Schlolaut G et al (2012) An automated method for varve interpolation and its application to the Late Glacial chronology from Lake Suigetsu. Japan Quat Geochronol 13:52-69

Schlolaut G et al (2014) Event layers in the Japanese Lake Suigetsu "SG06" sediment core: description, interpretation and climatic implications. Quat Sci Rev 83:157-70

Staff R et al (2011) New C Determinations from Lake Suigetsu, Japan: 12,000 to 0 cal BP. Radiocarbon 53(3):511-528. doi:10.2458/azu_js_rc.53.12340

Tarasov P et al (2011) Progress in the reconstruction of Quaternary climate dynamics in the Northwest Pacific: a new modern analogue reference dataset and its application to the 430-kyr pollen record from Lake Biwa. Earth Sci Rev 108(1-2):64-79

Wright HE (1967) The use of surface samples in quaternary pollen analysis. Rev Palaeobot Palynol 2(1-4):321-30. doi:10.1016/0034-6667(67)90162-5

Yang G et al (2007) Sediment rating parameters and their implications: Yangtze River. China Geomorphology 85(3-4):166-75

\section{Submit your manuscript to a SpringerOpen ${ }^{\odot}$ journal and benefit from:}

- Convenient online submission

- Rigorous peer review

- Immediate publication on acceptance

- Open access: articles freely available online

- High visibility within the field

- Retaining the copyright to your article

Submit your next manuscript at $\boldsymbol{\nabla}$ springeropen.com 